\title{
LEAD AND MANGANESE ACCUMULATION ON LEAVES OF ROAD SIDE PLANTS FROM MAURIPOR TO HAWKS BAY ROAD, KARACHI, PAKISTAN
}

\author{
Mohammad Salam, Farheen Mohsin, Farzana Mahmood, \\ InAYat Ur RAHMAN ${ }^{1}$, AfTAB AfZAL ${ }^{1}$ AND ZAFAR IQBaL ${ }^{1 *}$ \\ Chemical Lab., Karachi Institute of Power Engineering, Karachi, Pakistan
}

Key words: Accumulation, Conocarpus erectus, Environmental pollution

\begin{abstract}
In order to investigate the heavy metals accumulation and their effects on roadside trees Conocarpus erectus. The total content of $\mathrm{Pb}$ and $\mathrm{Mn}$ was determined using atomic absorption spectrophotometry was conducted. Average concentration $10.578 \pm 3.48 \mu \mathrm{g} / \mathrm{gm}$ of $\mathrm{Pb}$ and $91.98 \pm 30.03 \mu \mathrm{g} / \mathrm{gm}$ of Mn was found. Moreover, there were variations in the level of both these heavy metals in different samples of Conocarpus tree that were collected from different locations along the road side due to different level of exposure to $\mathrm{Pb}$ and $\mathrm{Mn}$. This physiological response of Conocarpus plant towards $\mathrm{Pb}$ and $\mathrm{Mn}$ suggests that roadside plants are good indicators of heavy metals accumulation and their subsequent effects on the environment.
\end{abstract}

The tremendous increase in auto vehicles in recent years has caused the environment to become a continuous source of pollutants, including heavy metals. Plants show considerable amount of lead and other metals in their tissues near busy roads (Dalal and Bairgi 1985, Rashid and Mukherjee 1990, Iqbal et al. 1999). Tetra-ethyl lead, which is an anti-knocking additive, is added to gasoline, that escapes from auto exhaust and mix into the air, soil and water (Iqbal and Shazia 2004). Lead has long been known as a potential health hazard (Shannon and Graef 1996). A number of studies have determined lead concentrations in dust, soil, particulates, and leaf samples in different urban areas around the world. Dust is a significant source of lead and can raise the blood lead levels in humans, particularly in children (Aydinalp and Marinova 2004). Manganese is used as a component of tyre and motor oil (Shaikh et al. 2006). Particulate type air pollutants such as ash, dirt and grit land on the top of leaves do not enter the leaf but may damage it by mechanical abrasion of surface. Particulate matter can also block the sun light and there by reduce the food processing ability of the plants. Deposition of lead on leaves mainly depends upon the characteristics of the leaf surface and the wind speed, and to lesser extent on the other environmental conditions like temperature, humidity etc. (Agarwal 1991). The plants, growing near highways are usually exposed to more automobile lead and manganese discharge than any other location. Small amount of lead, manganese and other heavy metals can penetrate the cuticle probably through stomata and other openings. In an earlier study, it has been found that stomata of plants growing on roadside and central district of Karachi are blocked to the extent of $20-50 \%$ depending on the location (Ahmed et al. 2005).

The present study was conducted in order to investigate heavy-metals ( $\mathrm{Pb}$ and $\mathrm{Mn}$ ) accumulation and their effects on roadside trees Conocarpus (Conocarpus erectus) in the Mauripor to Hawks bay Road.

Leaf samples of Conocarpus erictus tree were collected from eight kilometers area (from Mauripur to fish point (Beach Bar-BQ Restaurant), along Hawks bay road Karachi, Pakistan. There were four rows of plants; each row was composed of 1500 plants, so there were approximately

*Author for correspondence: <zafar.hu@yahoo.com>. ${ }^{1}$ Department of Botany, Hazara University Mansehra 21300, KP, Pakistan. 
6000 plants in this belt. Out of which 15 trees were selected for samples collection. The samples were collected from the row, which was exposed to high vehicles exhaust. Here is a dam, so the samples are named as D-1 and D-2. Collections were made in such a way that approximately the similar plant height was maintained. Initially leaves were collected along with shoots from all sides of the plants in a circle. 20 - 30 leaves were collected from different shoots of each plant randomly. Then each plant leaves were dried separately in an oven at $100^{\circ} \mathrm{C}$ for three hours. The dried leaves were ground to fine powder, and then it was sieved.

To remove the organic matter, digestion of the leaves powder was performed by using $1 \mathrm{mg}$ of the sieved powder. For this, $1 \mathrm{gm}$ of leaves powder was taken and mixed with $15 \mathrm{ml}$ of nitric acid and kept for whole night. The mixture was then heated 60 to $70^{\circ} \mathrm{C}$ for further digestion. During heating process, hydrogen peroxide and diluted sulphuric acid $(0.1 \mathrm{~N})$ were added gradually. The residue was diluted; filtered and heated again and again until white residue was obtained. These white residues were further analyzed as mentioned by Plank (1993).

Table 1. Lead and manganese concentration ( $\mu \mathrm{g} / \mathrm{gm})$ of collected plants samples.

\begin{tabular}{ccc}
\hline S. No. & Pb & Mn \\
\hline S-1 & 14.544 & 123.320 \\
S-2 & 15.152 & 072.330 \\
S-3 & 07.671 & 065.710 \\
S-4 & 13.352 & 116.410 \\
S-5 & 12.450 & 108.285 \\
S-6 & 10.732 & 083.485 \\
S-7 & 11.870 & 133.085 \\
S-8 & 11.242 & 073.280 \\
S-9 & 08.242 & 059.175 \\
S-10 & 09.395 & 109.392 \\
S-11 & 09.062 & 071.527 \\
S-12 & 04.327 & 053.485 \\
S-13 & 03.595 & 051.042 \\
D-1 & 11.347 & 110.710 \\
D-2 & 15.670 & 148.450 \\
\hline Average (S1 to 13) & 10.12 & 86.19 \\
Average (D1 to D2) & 13.50 & 129.58 \\
\hline
\end{tabular}

Results indicated variation in concentration for both $\mathrm{Pb}$ and $\mathrm{Mn}$. The lowest value was 3.595 $\mu \mathrm{g} / \mathrm{gm}$ and a highest of $15.67 \mu \mathrm{g} / \mathrm{gm}$ for lead and $51.0423 \mu \mathrm{g} / \mathrm{gm}$ to $148.45 \mu \mathrm{g} / \mathrm{gm}$ for manganese (Table 1) which were obtained from the sample No. S-13 and D2 in both cases. The variation in concentration of both pollutants (heavy metals) may be due to variations in exposure time to $\mathrm{Pb}$ and $\mathrm{Mn}$, location of shoots from which leaves were collected and location or position of the leaves on the shoot (road side or opposite). This may be due to leaf orientation, while the leaves of other species are somewhat more vertically oriented. Aydinalp and Marinova (2004) reported similar results that the particulate deposits per unit area of leaf were found to be greatest on the leaves of 
Ficus bengalensis might be due to leaf orientation. The other reason may be the position of the shoots; newly born shoots have less exposure time to pollutants, so they are less prone for pollution. Similarly if the plant age is lesser, then the exposure time of its leaves will also be lesser, so concentration of $\mathrm{Pb}$ and $\mathrm{Mn}$ deposit on leaves will be low.

The other things, which can be observed from the results, is a decreasing trend in concentration of $\mathrm{Pb}$ and $\mathrm{Mn}$, from S-1 to S-13. This may be because the plants along the start of Maripur were planted before those that were towards the Hawks bay road. Therefore, concentration in the plants leaves, which have more exposure time, is more than the other ones. From Mauripur to Hawks bay a decreasing trend in plants age is observed, and similar decreasing trend in concentration of $\mathrm{Pb}$ and $\mathrm{Mn}$ is also observed. The minimum concentration is that of S-13 because the age of the plant at this extreme is less, while maximum concentration other than D-1 and D-2 was that of S-1 which is due to more age. D- 1 and D-2 were taken from a remote area, a distance of approximately one $\mathrm{km}$ from main Mauripur road.

This area is safe from main road pollution, with only a small link road to the upper side villages, having extremely rare traffic. It was expected that the concentration of $\mathrm{Pb}$ and $\mathrm{Mn}$ would be less at this point, as it is away from the main road, but results showed highest concentration of both $\mathrm{Pb}$ and $\mathrm{Mn}$. The reason for this unexpected result is perhaps the more exposure time, as the plants were old trees. It was observed that the heavy pollutants like $\mathrm{Pb}$ and Mn have the ability to remain airborne for more than ten hours and in this time interval they can travel to large distance. The second reason is that the Dam is situated in the north of the main road and sea is in the south. High traffic density on this road is in the summer season because of the picnic points on the beach. In the summer season the direction of wind is from sea to land (i.e. towards Dam), and due to which pollutants were taken away by the wind from Hawks bay road to the Dam side area. Perhaps due to this reason, the concentration of $\mathrm{Pb}$ and $\mathrm{Mn}$ in samples D-1 and D-2 is more than the other samples.

EPA (2010) revised the level of the primary (health-based) standard for Pb from 1.5 micrograms per cubic meter $\left(\mu \mathrm{g} / \mathrm{m}^{3}\right)$ to $0.15 \mu \mathrm{g} / \mathrm{m}^{3}$, measured as total suspended particles (TSP) and revised the secondary (welfare-based) standard to be identical in all respects to the primary standard (EPA 2010). We found a higher concentration of $\mathrm{Pb}$ in our research as compared to the EPA standards. This shows a serious concern for human health and general safety. Similarly, EPA standards for manganese, average air levels are approximately 0.02 micrograms per cubic meter $\left(\mu \mathrm{g} / \mathrm{m}^{3}\right.$ ) equivalent to $0.0156 \mu \mathrm{g} / \mathrm{gm}$. We found an even higher concentration of $\mathrm{Mn}$ in our research. Kabata-pendias and Pendias (1994) reported that toxicity of Mn is commonly associated with acidic soils and warm climates. Its recommended value in plant issue is about 100-500 $\mathrm{mg} / \mathrm{kg}$. Critical values of $\mathrm{Mn}$ in most of the plants $200-300 \mathrm{mg} / \mathrm{kg}$ were reported whereas main source of Mn existing in air and soil was skid (Celik and Aslihan 2004).

In our current research work EPA standards for both $\mathrm{Pb}$ and Mn contents are crossed either considering ambient air quality or leaves concentration of $\mathrm{Pb}$ and $\mathrm{Mn}$, of the roadside plants. The possible reason for this high concentration of lead and manganese is automobile exhaust and industries affluent to air. At the same time, lead is used as an anti-knocking agent in gasoline. The other reason may be poor conditions of the engine of vehicles, which are unable to burn the fuel completely. As the fuel is not burned completely, so the unburned remains of the fuel come to the atmosphere as aerosol particulates, and thus causes air pollution.

All samples show a remarkable concentration of $\mathrm{Pb}$ and $\mathrm{Mn}$. Vehicles exhaust contains $\mathrm{Pb}$, which shows that gasoline is not lead free. $\mathrm{Pb}$ and $\mathrm{Mn}$ increased level in human blood causes many diseases. Quality of vehicles fuel shall have to be free of pollutants. 


\section{Reference}

Agarwal S 1991. Automobile pollution. In: S. Agarwal, Automobile pollution (p. 87). NEW Dehli 110026: ISBN.

Ahmed MF, Farrukh MA and Naqvi II 2005. Enviromental effects on heavy metals in road side plants of Eucalyptus and Guaiaculm officinale. J. Chem. Soc. Pak. 27(5): 286-289.

Aydinalp C and Marinova S 2004. Lead in particulate deposits and in leaves. Polish J. Environ. Stud.13(2): 233-235.

Celik A and Aslihan A 2004.Determining the heavy metal pollution in Denizli (Turkey) by using Robinia pseudo acacia L. Environ. Inter. 31(1): 105-112.

Dalal T and Bairgi P 1985. Effect of $\mathrm{Hg}$, As and $\mathrm{Pb}$ on germination and seedling growth of two jute varieties. Environ. Ecol. 3:403.

EPA 2010. Overview of airborne metals regulations, exposure limits, health effects, and contemporary Research. Andrea Geiger and John Cooper, Cooper Environmental Services LLC, 10180 SW Nimbus Ave., Ste J6 Portland OR 97223.

Iqbal MZ and Shazia Y 2004. Differential tolerance of Albizia lebbeck. Polish J. Environ. Stud. 13(4): 439442.

Iqbal MZ, Sherwani AK and Shafiq M 1999. Vegetation characteristics and trace metals (Cu, $\mathrm{Zn}$ and $\mathrm{Pb})$ in soils along the super highways near Karachi, Pakistan, Studia Botanica Hungarica 29: 79.

Kabata-pendias A and Pendias H 1994. Trace element in soil and plants. Second edition. Boca Raton, Florida: CRC, 365.

Plank CO 1993. Plants Analysis Refrence Procedure for Southren Region of United States. Georgia: Southren Cooprative Bulletin Series 368.

Rashid P and Mukherjee A 1990. Effect of lead nitrate on some anatomical features of mungbean. Bangladesh J. Bot. 19:149.

Shaikh GH, Hashmi DR and Siddiqui SI 2006. Accumulation of heavy matels and tarry deposite on leaves at varioius location of Karachi. J. Chem. Soc. Pak. 28(2): 125-128.

Shannon M and Graef JW 1996. Lead intoxication in children with pervasive developmental disorders. J. Toxicol. Clin. Toxicol. 34(2): 177. 